\title{
17. LA LUNE (THE MOON)
}

Président: A. Dollfus.

Vice-Présidents: A. A. Mikhailov, G. H. Pettengill.

SeCRÉtaIRE: Miss B. Middlehurst.

Comité D’Organisation: G. P. Kuiper, D. H. Menzel, M. G. J. Minnaert.

Selon les instructions reçues de la part du Secrétaire Général de l'UAI, l'esprit général du présent "Draft Report" de la Commission 17 "La Lune" ne doit plus représenter, comme par le passé, un résumé des travaux effectués dans la discipline au cours des trois dernières années. Son rôle sera de donner un aperçu général sur les aspects et les tendances des recherches sur la Lune, la contribution présente et future de la Commission 17 du l'UAI dans son développement, ainsi que les coopérations dont elle est l'objet ou devrait l'être dans l'avenir.

L'évènement le plus marquant de ces trois dernières années a été l'exploration directe de la Lune. Pour la première fois un homme, N. Armstrong, a posé le pied sur le sol lunaire, le 21 Juillet 1969, à $2^{\mathrm{h}} 56^{\mathrm{m}}$ T.U. Il était suivi peu après par E. Aldrin, tandis qu'un troisième co-équipier M. Collins, contribuait à la mancuvre. L'exploit, réussi par l'Organisation Américaine de Recherches Spatiales NASA, dans le cadre du programme "Apollo" a été renouvelé le 19 Novembre 1969 par C. Conrad, R. Gordon, et A. Bean. Ces missions d'exploration ont permis de ramener de très nombreux documents photographiques, une grande quantité d'échantillons sélectionnés du sol lunaire, de laisser sur le terrain des sismographes, des réflecteurs laser, des instruments de mesure de la densité de l'atmosphère lunaire, de l'intensité du champ magnétique, de la composition du vent solaire, etc.

Les possibilités nouvelles offertes à l'étude de la Lune par l'exploration directe entraînent une réorganisation fondamentale de la recherche dans ce domaine, dont nous allons examiner les implications concernant l'UAI.

\section{STRUCTURATION DE LA COMMISSION 17 DE L'UAI}

La Commission 17 de l'UAI La Lune a eu le regret de perdre l'un de ses Vice-Présidents, le Professeur A. Lebedinsky, décédé brusquement en mission scientifique, quelques semaines après sa nomination aux fonctions de la Commission. Il a été remplacé par le Professeur A. A. Mikhailov.

J. H. Focas est décédé le 3 Janvier 1969; il a été remplacé par le Professeur S. Miyamoto.

La Commission 17 de l'UAI s'est vu préciser sa mission de coordination des recherches lunaires internationales par le Comité Exécutif de l'ICSU de la façon suivante (ICSU Bulletin, 1966): "Commission 17 of the IAU, Commission of the Moon, is agreed to be the most appropriate body to coordinate studies of problems relating to the Moon."

Afin d'être en mesure de remplir la tâche de coordination des études lunaires que lui a confiées spécifiquement l'ICSU, dans le cadre du développement quasi explosif des recherches sur la Lune ces dernières années, la présente Commission a jugé efficace de diviser ses activités en 3 groupes de travail.

\section{Groupe de Travail: Nomenclature Lunaire}

Ce groupe de Travail a été créé lors de l'Assemblée Générale de l'UAI à Prague en 1967, avec pour mission:

"... The purpose of this Committee is the continuation of the work on Lunar Nomenclature, according to Resolution No. 8 adopted during the General Assembly at Prague in 1967: "The assignment of names and permanent designations to features on the far side of the Moon will be postponed until the XIVth General Assembly. As an interim measure, a Working Group will assign numbers to about 500 major lunar formations." It has been agreed that the members of this Committee - none of whom is personally and directly engaged in the work of Lunar Topography - 
should represent the work of each country through the National Astronomical Committees concerned. It is desirable that, in a general way, the work on Lunar Nomenclature be guided in conformity with the decisions already adopted by the IAU, defined by Resolution No. 2 of Commission 16, taken during the General Assembly at Berkeley in 1961 (Trans. IAU 11, 1961, 235) and completed by the list of names adopted in 1964 (Trans. IAU 12, 1964, 202)."

Ce travail avait été préparé les années précédentes par le Professeur Z. Kopal, chargé dès 1965 par la Commission d'explorer le domaine. La composition du groupe de travail en 1967 était:

D. Menzel (President), A. A. Mikhailov, M. Minnaert, A. Dollfus (ex-officio).

Au début de 1969, le Professeur Mikhailov a demandé à se faire remplacer par B. Levin. Le Groupe de Travail s'est réuni quatre fois en 1968-69 à Cambridge (Mass.), à Paris (France), à Moscou (U.R.S.S.), et à Meudon (France). Ses activités ont fait l'objet d'un rapport particulier préparé par le Prof. Menzel. Grâce à la consultation des Académies des Sciences de tous les pays membres de l'UAI, le Groupe de Travail a recensé un vaste choix de propositions de noms susceptibles d'être attribués à des cratères; elle en a effectué une sélection attentive, établi les biographies justificatives, recensé les cratères de la face arrière de la Lune dont les dimensions justifient une désignation, et attribué les noms en préservant une répartition alphabétique mnémotechnique. Des aménagements de la règle alphabétique sont apparues souhaitables pour une quinzaine de grands bassins d'une importance topographique évidente. La proposition résultant de ce travail doit être soumise aux remarques et à l'approbation de tous les membres de la Commission.

\section{Groupe de Travail: Figures et mouvements de la Lune}

Le champ des activités dont la Commission est responsable étant trop vaste, il apparut nécessaire de subdivider les membres en groupes plus restreints et plus spécialisés. Le premier groupe est concerné par les activités qui étaient antérieurement celles de l'ancienne Commission 17 "Mouvements et figures de la Lune" avant que ces attributions ne se soient élargies en 1965 . Th. Weimer (Observatoire de Paris, France) a accepté d'en assurer la mise en place en lui définissant des objectifs exploratoires initiaux limités:

"... The activity of this group should cover the following fields: cartography (except nomenclature), selenodesy, gravific potential, orbital movement (theory and observations), rotation (theory and observations).

"In a first state, the group would assume a mission of information and relationship. Each member should address to the chairman of the group reprints or summaries of all works he knows. The list and a short analysis of these publications will be sent by the chairman to all members."

Les personnalités suivantes ont accepté de participer à ces activités:

Membres de la Commission 17: Arthur, D. W. G., Eckert, W. J., Habibullin, S. T., Hall, R. G., Hopmann, J., Jakovkin, A. A., Kopal, Z., Koziel, K., Mikhailov, A. A., Nefediev, A. A., Potter, H. J., Weimer, Th.

Membres des autres commissions de l'UAI: Goudas, C. L. (Patras, Grèce); Shapiro, I. I. (Lexington, U.S.A.); Yaplee, B. S. (Washington, U.S.A.).

Membres extérieurs à l'UAI: Alley, C. N., Univ. of Maryland, U.S.A.; Carder, R., ACICUSAF, 2nd and Arsenal Street, St. Louis, Missouri 63118, U.S.A.; Hunt, M., AFCRL, Lunar Laser Field Unit, Lunar and Planetary Lab., University of Arizona, Tucson, Ariz. 85721, U.S.A.; Michael, W. H. Jr., NASA Langley Research Center, Hampton, Virginia 23365, U.S.A.; Orszag, Labor. de Physique Vignal, École Polytechnique, 17, Rue Descartes, Paris, France.

Des échanges réguliers de bibliographie sont en cours.

\section{Groupe de Travail: Lunar Geology and Geophysics (Géologie et Géophysique lunaires)}

Les nouveaux aspects de la physique lunaire résultant de l'exploration directe ouvrent le champ des recherches à de nouvelles disciplines. La nécessité d'y adapter la Commission 17 est évidente. La Commission possède parmi ses membres des spécialistes de géologie et géophysique, mais en 
nombre insuffisant et ceux-ci couvrent incomplètement la discipline; de nombreuses personnalités, membres de la Commission ou extérieurs, ont insisté sur le besoin de les regrouper dans leur spécialité, selon la formule du Groupe de Travail (Working Group) qui possède l'avantage de pouvoir s'adjoindre des participants non membres de l'UAI pouvant appartenir à des disciplines autres que celles de l'Astronomie:

"The principal aim of the Working Group "Lunar Geology and Geophysics" is to assist with the Geological and Geophysical Interpretation of the Moon in close connection with astrophysical implications. The Working Group might also wish to make recommendations about the most efficient means of analysing the lunar surface and interior, including returned samples."

G. Fielder a accepté de mettre en place ce Groupe de Travail comprenant au départ les membres concernés de la présente commission 17 de l'UAI, et un représentant de chacune des autres Associations Internationales concernées. Ce groupe devra s'adjoindre des spécialistes, géologues et géophysiciens appropriés:

Membres appartenant à la Commission 17: Kuiper, Levin, Liddel, Martynov, Menzel, Middlehurst, Minnaert, Miyamoto, O'Keefe, Shoemaker, Strom, Urey.

Représentants des unions scientifiques: Dollfus (Union Astronomique Internationale); Elston (American Geophysical Union); Fielder (International Union of Geological Sciences); Green (International Association of Planetology); Kaiser (Inter-union Commission on solar terrestrial physics) Dept. of Physics, Univ. of Sheffield, England; Pettengill (Union Radio Scientifique Internationale); Runcorn (Union Géodésique et Géophysique Internationale); School of Physics, Univ. of Newcastle upon Tyne, England; Sagan (COSPAR); Tazieff (International Association on Volcanology and Chemistry of the Earth's Interior) 15 Quai Bourbon Paris 14, France.

L'une des premières activités dépendant de ce Groupe de travail se trouve être la préparation d'un "Catalogue des cratères terrestres et structures connexes", entrepris par J. Fryer et C. Titulaer, à l'Observatoire de Meudon, avec l'appui de "European Space Research Organization" (ESRO). Le but est défini ainsi:

"... Ce catalogue est destiné à permettre une étude des cratères de toutes dimensions, comprenant les petites cavités artificielles, ou d'origine volcanique, les dépressions formées par les effondrements, les impacts de météorites jusqu'aux plus grands types connus. Il devra comprendre également le plus grand nombre d'informations accessibles relatives aux dimensions, à la position, à l'histoire géologique de ces cratères, etc."

La première partie du catalogue concerne le Canada et doit être publiée au début de 1970 ("Catalogue Général des formations géologiques circumlunaires terrestres: Partie I, Canada.")

\section{NOUVELLES ORGANISATIONS INTERNATIONALES}

Deux nouvelles Organisations Internationales se sont trouvées concernées par l'extension du domaine des études sur la Lune ces trois dernières années: le COSPAR et l'IUGS. La présente Commission de l'UAI a qu à définir, avec les intéressés, les domaines respectifs et les modes de coopération entre ces organismes:

(a) COSPAR: A la suite des entretiens avec les responsables des Commissions 16 (Planètes) et 17 (Lune) de l'UAI, le COSPAR a créé un Groupe de Travail W.G. VII: "Space-related studies of the Moon and Planets". Les attributions de ce Groupe de Travail se définissent ainsi:

"... Working Group VII is: - to organize meetings within COSPAR on the subject of its title - to coordinate its activities with interested Unions, particularly with Commissions 16 and 17 of the International Astronomical Union and Commission V of the URSI - and to function otherwise in a manner similar to the other Working Groups. COSPAR intends to leave such traditional matters as lunar and planetary nomenclature and cartography entirely to the IAU."

Les membres du Working Group VII du COSPAR sont les suivants:

Chairman: A. D. Kuzmin, Lebedev Physical Institute, Moscow, U.S.S.R.

Vice-Chairman: C. Sagan, Center for Radiophysics and Space Research Cornell University, Ithaca, N.Y., U.S.A. 
Membres: Abysov, S. S.; Colombo, G.; Dollfus, A.; Drake, F. D.; Eshelman, V.; Florensky, C. P.; Hall, J.; Hayakawa, S.; Johnson, F. S.; Kopal, Z.; Kuiper, G. P.; Levin, B. J.; Link, F.; Marov, N.; Mayer, C.; Ness, N.; Pimentel, G.; Prokofiev, V. K.; Rea, D.; Shoemaker, E. ; Troitsky, V.S.

(b) IUGS: L" "International Union for Geophysical Sciences" a accepté l'affiliation d'une organisation nouvellement créée, 1' "International Association of Planetology (IAP). Cette Association définit ainsi ses buts:

"... Our charter specifically deals with the investigation of planets, their satellites, and interplanetary matter from a geoscientific point of view. The research methods employed are geological, geophysical, geochemical, meteorological and astronomical, supported by recently acquired astrophysical and astronautical data."

La composition initiale de cette Association est:

Président d'honneur: G. N. Katterfeld.

Président: J. Green.

Secrétaire Général: Madame N. Stovickova.

Vice-Présidents: S. Miyamoto, H. Tazieff, K. von Bülow, K. Rankama, P. Hedervari, K. Beneš.

Les attributions de l'IAP et son incorporation dans la coordination internationale ont résulté de nombreux échanges de lettres entre les membres concernés de la Commission 17, son Président, et les membres du bureau de l'IAP.

\section{IMPORTANTES INITIATIVES DE COORDINATION}

(a) La branche de l'organisation américaine de recherches spatiales NASA, "Apollo Lunar Exploration Office", dirigé par L. R. Scherer, a joué un rôle d'une importance particulière pour les domaines couverts par notre Commission. Elle a assuré la conception et la coordination des opérations qui ont conduit à l'exploration directe de la Lune et à l'exploitation scientifique des observations effectuées.

Les travaux ont conduit, notamment, à la mise en place au Manned Space-flight Center, Houston, Texas du "Lunar Receiving Laboratory" dirigé par E. King, puis par A. Callio, dont les objectifs sont les suivants:

"Functions of this laboratory are as follows: (1) to quarantine the lunar material for an appropriate period of observation; (2) to perform a preliminary examination of this material (chemical, mineralogical, and other examinations); (3) to perform certain time-critical experiments which could not wait until the end of quarantine; and (4) to distribute the lunar samples to approved investigators and to be depository for the permanent collection of lunar materials."

Afin d'assurer une étude scientifique exhaustive des premiers échantillons du sol lunaire ramenés sur Terre par la mission spatiale Apollo XI, $4 \cdot 2 \mathrm{~kg}$ de poudre lunaire, et 30 blocs rocheux d'un poids total de $4 \mathrm{~kg}$ ont été distribués en Septembre 1969 à 106 laboratoires américains et 36 laboratoires de tous autres pays, tous sélectionnés sur les critères de leurs compétences particulières. Les résultats des différentes études ont fait l'objet d'une confrontation lors d'une conférence internationale en Janvier 1970 à Houston, Texas, et feront l'objet d'un rapport final unique dans la revue Science.

(b) La nouvelle publication scientifique "The Moon - An International Journal of Lunar Studies", Éditeurs H. Alfvén, Z. Kopal, H. C. Urey, Éditions Reidel, Dordrecht, Hollande. Premier fascicule paru en Novembre 1969. Les éditeurs définissent ainsi le but du journal:

“... The Moon is a journal which provides an inter-disciplinary but monothematic medium for publication of the results of original investigations in all fields of lunar studies, including: astronomy (both optical and radio-astronomy), astronautics, chemistry, geology, space physics, and all other aspects of the scientific study of our satellite by spacecraft as well as by the more traditional approaches of ground-based astronomy. In addition, the editors of this journal expect to publish from time to time invited review papers in the form of a critical discussion on problems of current interest; and keep a column open for book reviews, as well as reports on international meetings concerned with any aspect of lunar studies. An integral part of each issue of our journal should be 
a current critical bibliography of the entire field of lunar studies - an essential and truly indispensable service for a rapidly growing interdisciplinary domain of our science - containing titles, abstracts, or critical comments, on work published concurrently in all other journals or more informal sources."

(c) Le "National Space Science Data Center" de la NASA (Goddard Space-flight Center - Code 601 - Greenbelt, Maryland 20771 - USA) définit ses responsabilités ainsi :

“... The National Space Science Data Center (NSSDC) was established by NASA to further the widest practicable use of reduced data obtained from space science investigations and to provide investigators with an active repository for such data. As such, it is responsible for the active collection, organization, storage, announcement, retrieval, dissemination, and exchange of data received from satellite experiments, sounding-rocket probes, and high altitude aeronautical and balloon investigations."

Ce Centre de Documentation regroupe en particulier tous les clichés et les mesures recueillis par les sondes spatiales Ranger, Surveyor, Orbiter, Explorer, Apollo, etc., et les tient disponibles pour des programmes de recherches scientifiques. Chaque nouvelle série de documents fait l'objet d'un "Data Announcement Bulletin."

(d) Le "Lunar International Observers' Network" (LION) of the Smithsonian Institution Center for short-lived phenomena" dirigé par R. Citron (Cambridge, Mass., U.S.A.) et décrit comme il suit:

"The Lunar International Observers' Network was organized by Miss Barbara Middlehurst during the past several years and now includes 176 astronomers in 31 countries around the world. The network is composed of professional and amateur astronomers who have particular interest in transient lunar phenomena .... The main objectives of these observing programs are to record the nature, magnitude, frequency, and distribution of transient lunar phenomena, and possibly obtain independent correlation of events from widely separated groundbased observatories."

A l'occasion de la mission de survol circumlunaire Apollo X, les observations ont permis de maintenir la Lune sous surveillance 24 heures par jour pendant 6 journées consécutives; 23 phénomènes lumineux ont été enregistrés dans 8 régions lunaires différentes. (Cf. "Communications Support for Transient Lunar Phenomena during the Apollo X Mission 28 May 1969, Smithsonian Institution Publications".)

\section{COMMENTAIRES SUR LE RÔLE DE LA COMMISSION 17}

La conduite des responsabilités de la Commission 17 a nécessité des consultations et échanges de nombreuses correspondances avec les membres de la Commission et avec d'autres personnes qualifiées. Voici quelques extraits de lettres choisis pour exprimer qualques-uns des besoins de la Commission:

\section{Observations par le laser}

- “... Pour la mise en oeuvre et l'exploitation de ces nouvelles possibilités, la coopération internationale est plus nécessaire que jamais. Mais cette technique n'étant plus, en général, du ressort des astronomes et des observatoires astronomiques au sens classique, il est urgent de compléter la Commission 17 par la nomination de nouveaux membres faisant des recherches dans ce domaine. Le Groupe de Travail "Figures et Mouvements de la Lune" créé au cours de l'été 1968 est un premier pas vers cette coopération internationale active."

- “... Des résultats ont été obtenus aux États-Unis par le groupe de Faller (Observatoire Lick); le groupe de Alley (Observatoire McDonald); par le groupe d'Eckhardt (Tucson) et par Orszag (Pic-du-Midi). Actuellement, en plus d'une coopération étroite entre les groupes de J. Faller et de C. O. Alley, il existe une coopération entre le second de ces groupes et le Pic-du-Midi. Certains contacts, d'autre part, étaient pris dans le cadre de la coopération franco-soviétique avec le groupe Kokurin. Un rôle possible pour la Commission 17 de l'UAI pourrait être d'encourager ces coopérations, en particulier dans la mesure où la mise en commun des résultats émanant de stations assez uniformément réparties en latitude accroît notablement la précision des déterminations lunaires." 


\section{Observations par le radar}

- "At the present, all radar astronomy, both lunar and planetary, appears to be concentrated in the U.S.A. For this reason, the part played by the IAU in coordinating radar observations is minimal and will likely remain so."

\section{Champ gravitationnel et concentrations de masse}

- “... Commission 17 could attempt to encourage an international effort in application and interpretation of these results. Scientists not involved in particular experiments will, nevertheless, have access to the results, and they could conduct research investigations applying the results at a different point of view from those initially involved. Also, there will probably be numerous interesting areas of research in which multi-disciplinary information should be combined for particular objectives."

\section{Luminescence du sol lunaire}

- “... Parallèlement aux observations du sol lunaire, d'excellentes études de simulation du phénomène en laboratoire ont été menées ces dernières années. Particulièrement, l'analyse spectrale de la luminescence créée par bombardement de protons sur différentes roches (Geake et Alley, 1967; Nash, 1966), et l'étude de la thermo-luminescence (Blair et Edgington, 1968; Sun et Gonzalez, 1966). On voit l'intérêt de premier ordre de ces travaux de laboratoire lorsque les matériaux utilisés seront des roches lunaires. Un programme de collaboration s'impose entre les expériences en laboratoire et les observations de la luminescence lunaire à partir du sol."

\section{Échantillons du sol lunaire}

- "... The recent search of interest in the analysis of returned lunar material had led to the application of many specialists techniques to lunar studies. The investigators using these techniques should be invited to participate in a Commission 17 meeting: the importance of their producing results and of their analysis within the medium of the IAU should be stressed. Only if Commission 17 can be fed with all these pertinent data, will it be in a position to make balanced recommendations for the future of Lunar research."

\section{Groupe de Travail "Géologie et Géophysique Lunaires"}

- "... Exchange of views between those schooled in the disciplines Astronomy, Geology, Geomorphology, Meteorology, Geophysics, would be especially desirable within the forum of Commission 17. Therefore, members of the new Commission 17's structure should be selected from these disciplines as a minimum requirement. Furthermore, there should be representatives of all international and national bodies concerned with lunar studies.... I propose that, in the first instance, this Working Group should (a) nominate representatives for the main body of Commission-17, following the above scheme; (b) advise Commission 17 of the most useful and efficient way to organize and run meetings. It may be desirable for the Working Group to make recommendations about the most efficient means of analyzing the lunar surface (including returned samples) and interior; but the principal aim of the Working Group would be to assist in general terms with the geological and geophysical interpretation of the Moon in close connection with the relevant astrophysical topics."

- “... Pour le moment, il me semble en effet que la Commission 17 de l'Union Astronomique Internationale est l'organisme le plus indiqué pour constituer un tel groupe de travail. Je ne suis pas sûr qu'à l'avenir ce groupe restera le point de rencontre central."

- "... It must be assured that the quantitative astronomical, astrophysical, geophysical and geochemical approach will dominate the qualitative, descriptive, geological approach." 
- "... I would not endorse any external policy-making recommendations of this Working Group in the area of Geosciences. This responsibility should probably be within the International Union of Geological Sciences, or within the International Union of Geodesy and Geophysics. Traditionally, the IUGS and the IUGG have had the authority to pass judgment on geoscientific recommendations made by any recognized national or international groups, when this recommendation was of international policy-making significance in the fields of geology, geophysics, and geochemistry."

- "... The problems of lunar geology involve the bringing together of a wide range of scientists. The assimilation and understanding of the flood of data which is pouring in on us will be a task not only for the astronomers in the countries who possess facilities for experiment and observation, but also for the countries where theoretical research dominates. It often happens that a theoretical man will hesitate to attack a problem because he is not sure what the exact observational situation is. Hopefully, this Working Group can add the isolated workers to contribute to the overall understanding of the Moon."

\section{Rôle général de l'UAI}

“... Commission 17 should recommend the release of national funds to activate personal exchanges on a regular footing. This is a most efficient way of disseminating knowledge and giving birth to new ideas. The way in which the IAU can assist in this aim is by drawing attention to the work done by various national groups, individuals, and by disseminating this knowledge sufficiently widely and with some direction, to assist research workers throughout the world."

- "... Commission 17 must respond to the modern trends and rapidly adapt itself to advise on the coordination of the various inter-disciplinary activities in different countries. The first requirement is to adjust the membership of Commission 17 to take in interests previously absent from its ranks.... Selected abstracts should be circulated to both professional and amateur lunar workers. Of necessity, a list of such workers should be prepared."

- "...I I have thought about the future relations between Commissions 16 and 17 of the IAU.... It seems clear that there is much to be said for combining the functions of the two Commissions ultimately since the IAU's role in lunar science will not differ from that in planetary science (problems of nomenclature, international organization of worthy scientific projects, definition of coordinate systems, etc.). These functions were already combined before in Commission 16. Nevertheless, we also felt that with the nomenclature questions concerning the Moon and Mars now pending, it would be destructive to have the organization changed already at the next meeting (1970). Rather, a period of adjustment would seem indicated so that reunification would probably be made more appropriately in 1973 ..."

- "... Recent experience has made me feel that coordination of the many groups in such diffuse fields as Moon and planets would be impossible, that we are already witnessing too much competition for limited attention." 